\title{
MARIANO LUIS DE URQUIJO, TESTIGO Y PROTAGONISTA INVOLUNTARIO DEL MOTÍN DE LA "ZAMACOLADA" (1804)
}

\author{
Aleix Romero Peña \\ Universidad de La Rioja
}

RESUMEN: En el presente trabajo analizamos la conducta mostrada por Mariano Luis de Urquijo durante el motín conocido como la Zamacolada, aportando además nuevas informaciones sobre este suceso.

Palabras clave: Mariano Luis de Urquijo, plan militar, fueros, matxinada, Juntas generales.

ABSTRACT: In this work we analyze the Mariano Luis de Urquijo's behaviour for the rebellion called Zamacolada, providing new information about this event.

Keywords: Mariano Luis de Urquijo, plan militar, fueros, matxinada, Juntas generales.

La Zamacolada es un hecho crucial en la historia contemporánea vasca y, como tal, hay una inmensa producción bibliográfica, entre la que destacan dos monografías de reciente publicación ${ }^{1}$. Se conocen además los testimonios de algunos testigos del suceso, que fueron reproducidos por el historiador Camilo de Villavaso. Se trata de una "Memoria confidencial y justificativa" compuesta por José María de Murga, miembro del ayuntamiento de Bilbao y apoderado en las Juntas de finales de agosto de 1804; y el "Extracto de una representación ele-

1. GUEZALA, Luis de: Bizkaia por sus fueros. La Zamakolada, Bilbao, Juntas Generales de Bizkaia, 2003; RIBECHINI, Celina: De la Guerra de la Convención a la Zamacolada. Insumisión. Matxinada. Dispersión, Donostia, Txertoa, 1996. 
vada por el teniente general don José de Mazarredo al rey". No obstante, continúan siendo poco conocidos otros relatos que suministran más luz sobre la Zamacolada, como el realizado por Mariano Luis de Urquijo.

Entre los papeles conservados en el Archivo Histórico Nacional, en la sección de "Consejos", se encuentra el proceso emprendido contra Mariano Luis de Urquijo por su participación en la Zamacolada. Los documentos comprenden cartas dirigidas al príncipe de la Paz, diversas testificaciones y pruebas sobre la actuación de Urquijo, y el minucioso interrogatorio judicial al que se le sometió, lo que confiere a su exposición un carácter más detallado y objetivo que las ya comentadas. Además, dicho interrogatorio tiene la particular ventaja de que fue realizado el 30 de septiembre de $1804^{2}$, apenas concluido el motín, mientras que las restantes son de finales del mismo año ${ }^{3}$. La investigación histórica sobre la Zamacolada precisa conocer el testimonio de Mariano Luis de Urquijo.

\section{Urquijo y Bilbao}

Aunque nacido en Bilbao en 17694, Mariano Luis de Urquijo creció en Madrid, a donde se trasladó su familia cuando tenía pocos años. Tras realizar estudios universitarios en Salamanca, regresó a la Corte e ingresó en la carrera burocrática, alcanzando por promoción la dirección de la Secretaría de Estado en $1798^{5}$. Durante apenas dos años y unos pocos meses permaneció como ministro, implementando reformas ilustradas. Su caída sobrevino como consecuencia de una conjura palaciega en la que la facción ultramontana cortesana se alió con Godoy y el nuncio del Vaticano para desalojarle del poder ${ }^{6}$. El 13 de diciembre de 1800 fue exonerado de su cargo por el rey Carlos IV. No se le comunicó la destitución, sino que se le conminó a abandonar la Corte y partir al pueblo más cercano a esperar instrucciones, prohibiéndosele mientras tanto

2. AHN, Consejos, leg. 51535, Pieza 12, f. 21.

3. Villavaso data la memoria de Mazarredo, "según noticias que consideramos seguras" a finales de 1804. La representación de Mazarredo está fechada el 8-XII-1804. Su versión impresa es de 1810. V. VILLAVASO, Camilo de: La cuestión del Puerto de la Paz y la Zamacolada, Bilbao, Juan E. Delmas, 1887, Apéndice I, Murga, p. 75, y Apéndice VII, Mazarredo, p. 227.

4. AHEB-BEA, Libro de bautismos 1759-1775, f. 164 №.

5. Aparte de la precocidad y de que su carrera se basara principalmente en los méritos, Urquijo fue pionero en dotar a su actividad ministerial de un carácter político, preludiando el modelo que presentaría la Secretaría durante su supervivencia en el Estado liberal. V. FRANCO RUBIO, Gloria, NAVA RODRÍGUEZ, María Teresa y LÓPEZ-CORDÓN, María Victoria: "Perfiles socioprofesionales de la burocracia española en el siglo XVIII: las Secretarías de Estado y del Despacho", en La burguesía española en la Edad Moderna: actas del Congreso Internacional celebrado en Soria los días 16 a 18 de diciembre de 1991, v. 3, Madrid, Fundación Duques de Soria, 1996, p. 1011.

6. V. SIERRA NAVA, Luis: La caída del primer ministro Urquijo en 1800, Madrid, CSIC, 1963. 
todo tipo de contacto con los monarcas ${ }^{7}$. En la población madrileña de Las Rozas recibió la orden de marchar a Bilbao, donde se le comunicó que recibiría una renta de mil doblones anuales ${ }^{8}$.

El 17 de marzo de 1801 el alcalde de Corte, don Sebastián de Torres, se desplazó a Bilbao para notificarle su arresto y trasladarlo a la ciudadela de Pamplona. En unos papeles posteriores Urquijo comentó que el motivo del proceso fueron dos cartas que su criado recibió de los embajadores bátavo y sajón -que, por otra parte, eran amigos de Urquijo- cuando fue a Madrid a vender los muebles y efectos personales de su señor, siendo interceptadas más tarde en la aduana de Orduña9. A pesar de sus pasados servicios a la corona, no hubo ninguna consideración con Urquijo. El marqués de las Amarillas, virrey de Navarra, advirtió por carta a Madrid que se disponía a aceptar en sus prisiones a Urquijo, aunque no contaba de disposiciones para ello, pues:

"no cabe en lo posible que Torres trajese aquí esta persona sin orden para ello, suponiendo haber sido un olvido natural, y he prevenido, como V. E. verá por las adjuntas copias, que se le ponga si (sic) comunicación en los mismos términos en que estuvo el señor Conde de Floridablanca, lo que continuará hasta que S. M. se digne darme sus órdenes para el modo con que debe tratársele $[\ldots]^{\prime \prime}{ }^{10}$.

El sucesor de Urquijo al frente de la Secretaría de Estado, Pedro Cevallos, le contestó manifestándole la aprobación real a su proceder ${ }^{11}$. Urquijo y su sirviente, Francisco de Garay, fueron instalados en un cuarto de la habitación del sargento mayor de la ciudadela, que había muerto de tisis. Los dos prisioneros dormían en las camas prestadas por un inválido, encerrados en cuatro paredes que transpiraban humedad, sin contacto alguno con el exterior, víctimas de las pulgas y las enfermedades. Apenas comían, las piernas se les habían hinchado por la falta de ejercicio y su única distracción era la lectura, que realizaban de forma casi compulsiva. Los exhaustivos interrogatorios a los que fue sometido Urquijo resultaron infructuosos.

El 5 de octubre de 1802 los detenidos recibieron la libertad como una gracia otorgada por los reyes con motivo de los matrimonios de sus hijos el príncipe de Asturias y la infanta María Isabel ${ }^{12}$. Según la versión de Urquijo, el final del encie-

7. V. URQUIJO, Mariano Luis: Apuntes para la memoria sobre mi vida política, persecuciones y trabajos padecidos en ella, edición de Aleix Romero Peña, Logroño, Sin Índice, 2010, pp. 86-87.

8. AHN, Estado, leg. 3440, expediente $\mathrm{n}^{\circ}$ 18. Real Orden de 31-XII-1800.

9. V. URQUIJO, M. L., op. cit., pp. 90-93.

10. AHN, Estado, leg. 3440, expediente no 18. Marqués de las Amarillas a Cevallos. Pamplona, 23-III-1801. Tanto este como otros textos de la época reproducidos en este artículo seguirán las normas ortográficas modernas.

11. Ibídem. Cevallos al marqués de las Amarillas. Aranjuez, 27-III-1801.

12. Ibídem. Caballero a Urquijo. Barcelona, 5-X-1802. 
rro fue precedido por un intercambio epistolar con el príncipe de la Paz. Godoy respondió a su antiguo subordinado que no solo no había tenido nada que ver con su prisión, sino que aprobaba la política que había seguido durante su etapa como Secretario de Estado. El proceso, en cualquier caso, se había debido, según escribe Urquijo, "a mis obras indiscretas y a la fogosidad de mi carácter que había exaltado mucho la rapidez de mi carrera" ${ }^{\prime 13}$. Con el miedo metido en su debilitado cuerpo regresó a Bilbao. La persecución también había afectado a su familia, obligando a su padre, presidente del Consejo de la Mesta, a marchar a Bilbao ${ }^{14}$. Sin embargo, puede decirse que dentro de la desgracia fue de los más afortunados: Jovellanos permaneció preso durante seis años en el mallorquín castillo de Bellver.

El confinamiento en Bilbao impuso grandes estrecheces, que Urquijo buscó paliar en cuanto pudo. Como la de la residencia. Urquijo escribió a Pedro CevaIlos en 1803 quejándose de la casa en que se hospedaba, "un cuarto $3^{\circ}$ muy estrecho". Deseaba hacerse con la de don Martín de Epalza o con cualquier otra que se hallaba desocupada. Cevallos accedió a las peticiones de Urquijo ${ }^{15}$. Villavaso sitúa la vivienda de Urquijo en el Arenal, esquina con la calle Bidebarrieta, frente a la ría ${ }^{16}$. Esta casa, más confortable y espaciosa, permitió a Urquijo atender a diversas personalidades locales, atraídas por el recuerdo de la influencia del antaño poderoso ministro, ahora simple consejero de Estado honorario. No se trata de una cuestión baladí, pues la casa de Urquijo habría de convertirse en uno de los escenarios principales de la Zamacolada.

La vida de Urquijo en Bilbao se caracterizó por una enorme discreción. Solo regresó al plano público cuando Godoy fue elegido alcalde de la Villa, en 1803, y este lo eligió para que tomase posesión en su lugar. El nombramiento como regidor del príncipe de la Paz se debía a una maniobra del ayuntamiento bilbaíno para granjearse el apoyo de la Corte en las diferencias que mantenía con el Señorío de Vizcaya como consecuencia de la controvertida construcción del Puerto de la Paz en la anteiglesia de Abando. Por tanto, el día 31 de enero de 1803, rodeado de toda la pompa y el boato que requerían las circunstancias, Urquijo recogió la vara real ${ }^{17}$. En la alocución que Urquijo realizó al efecto predicó "paz y unión general". Durante la comida que siguió al acto Urquijo prosiguió con su actitud conciliadora recordando a los representantes del Señorío, de

13. V. URQUIJO, M. L., op. cit., p. 104.

14. Ibídem, p. 96.

15. AHN, Estado, leg. 3440, expediente no 18. Urquijo a Cevallos, 19-IV-1803. El episodio se encuentra referido en LEQUERICA, José Félix de: "Un ex ministro busca casa en Bilbao", en Soldados y políticos, Bilbao, Editorial Voluntad, 1928, pp. 362-370.

16. V. VILLAVASO, C.: op. cit., Murga, p. 49, nota 1.

17. V. GUIARD, Teófilo: Historia de la noble villa de Bilbao, v. 4 (1800-1836), Bilbao, La Gran Enciclopedia Vasca, 1971, pp. 20-22. Además del acto de posesión, con presencia de las autoridades, la ceremonia se compuso de una procesión por las calles de Bilbao con salvas de artillería, un brindis ofrecido por el concejo y diversos festejos públicos. 
la Villa y del Consulado, la principal institución comercial de Bilbo, que se hallaban también invitados, que eran hijos del mismo país. Urquijo sabía que ese día iba a ser aprovechado por miembros de uno y otro bando para que intermediara en el pleito; ya había recibido con anterioridad la visita de Simón Bernardo de Zamacola, comisionado en la Corte $^{18}$ y del corregidor Luis Marcelino Pereira, con análogas intenciones. A todos despachó con argumentos similares: "Mi respuesta fue que me hallaba malo, aunque el Médico decía que no, y así es que volví a tener una segunda enfermedad. Que mi espíritu estaba muy abatido con tanta desgracia y trabajos como los que había sufrido en mi prisión. Que además de eso, ni por el mismo carácter que él decía debía, ni podía yo mancharme en negocios de Pueblos, ni lo haría jamás: Que los exhortaba a la paz, pues al fin todos eran unos, y sobre todo, que no molestasen la superioridad con recursos, pues esto solía traer fatales consecuencias y el País se perdería"19.

Tan celoso se mostró Urquijo en cuidar su nueva vida de retiro, negándose en redondo a participar en los asuntos públicos, que llegó al extremo de impedir las visitas de un viejo amigo suyo, Lope García Mazarredo, al que le había tocado en suerte el cargo de procurador del Consulado ${ }^{20}$. Esta remisa actitud constituía el contrapunto más evidente de la que había desplegado durante su breve etapa como secretario de Estado, cuando se convirtió en valedor de uno de los dos bandos enfrentados por el control municipal de la Villa ${ }^{21}$. Probablemente este retraimiento se debiera a su convicción de que una conducta discreta y reservada era el mejor salvoconducto para recuperar la confianza de los reyes y regresar a la Corte. Los hechos de la Zamacolada truncaron una estrategia pacientemente calculada.

18. Zamacola y Urquijo mantenían cierta relación de amistad, que fue utilizada por los enemigos del primero durante el proceso político sufrido por el protagonista de este trabajo. Aprovechando que Zamacola partía a Madrid, se denunció que en una posada de Orduña había recibido "ciertos pliegos de correspondencia secreta entre Urquijo y un ministro o encargado de negocios de una corte extranjera". Zamacola y los amigos que le acompañaron en el viaje fueron prendidos, aunque pronto se demostró la falsedad de la delación. V. ZAMACOLA, Juan Antonio de: Historia de las naciones bascas de una y otra parte del Pirineo septentrional y costas del Mar Cantábrico, Auch, Viuda de Duprat, 1818, v. II, pp. 183-184, n. 186.

19. AHN, Consejos, leg. 51535, pieza 12, f. 2.

20. Ibídem, ff. 2-3. Hay testimonios que señalana sin embargo algún tipo de actividad, como el de don José María de Murga, diputado del Señorío, quien dice que Urquijo promovió la conciliación pero sin resultados. V. VILLAVASO, Camilo de: op. cit., Murga, p. 25.

21. V. GUIARD, T: op. cit., pp. 2-3, nota. Los bandos se habían formado como consecuencia de la huida de la parte de la corporación municipal tras la invasión francesa de Bilbao en 1795. Uno estaba compuesto por los que habían huído, el otro por quienes firmaron la rendición. Estos últimos fueron tomados como rehenes y sufrieron cautiverio hasta la firma de la paz de Basilea. Las disputas entre ambas facciones durante la posguerra les llevó a solicitar el amparo de la corte. Fue la facción de quienes se quedaron, liderada por el comerciante bilbaíno José Joaquín de Castaños, la que recabó según Guiard el apoyo de Urquijo, así como el de Simón Bernardo de Zamacola. 


\section{La Zamacolada, tal y como la vivió Urquijo}

El 17 de noviembre de 1803 fue ratificada la Real Orden del 31 de diciembre de 1801 por la que se habilitó la construcción de un puerto en Abando, que habría de gozar de las mismas libertades que el de Bilbao. El proyecto se enmarcó en un larvado enfrentamiento entre el Señorío y la Villa, pues la pujanza económica y el incremento demográfico de esta última, además de los privilegios que poseía, condicionó el desarrollo del resto del territorio. Los esfuerzos por impedir la validación del denominado Puerto de la Paz -bautizado así en alusión al príncipe de la Paz-, entre los que se encontraba el ya comentado nombramiento de Godoy como alcalde honorífico, resultaron infructuosos. De todas formas, la victoria colocó sobre la cabeza del Señorío la afilada espada de Damocles.

El 5 de mayo de 1803 el ministerio de la Guerra ordenó al corregidor vizcaíno que hiciera una leva entre los "vagos y malentretenidos" para incorporarlos al ejército. Un mes más tarde este mismo ministerio estableció un cupo de dos mil hombres, repartidos entre el Señorío, las dos provincias de Álava y Guipúzcoa, y el reino de Navarra, para que prestaran el servicio de armas. Estas disposiciones entraban en colisión con los fueros, los cuales excluían las quintas salvo para tiempos de guerra, cuando los habitantes defendían la tierra conformando milicias, como ocurrió durante la Guerra de la Convención de 1793. Los vascongandos tenían por honor la dispensa militar, por lo que cualquiera variación de la misma era susceptible de provocar malestar entre la población ${ }^{22}$.

La noticia del servicio militar llegó en un momento de euforia colectiva. Las Juntas Generales que se celebraron en Gernika a finales de julio de 1804 tuvieron como protagonista destacado a Zamacola, quien tras la derrota inflingida a la Villa y el Consulado fue recibido como el "héroe libertador del país" ${ }^{23}$. Por esa razón, Zamacola dedicó principalmente su discurso de tres horas, en castellano y en vascuence, a dar cuenta de la gestión de su misión sobre el asunto del Puerto de la Paz. Solo al final habló del servicio militar. Temiendo que los arrestos emprendidos por el corregidor provocasen algún tipo de alteración, consiguió la suspensión de la Real Orden hasta que las Juntas ordinarias del Señorío dispusieran una ley más acomodaticia con las libertades vizcaínas. Zamacola terminó la perorata siendo ovacionado por todos los presentes ${ }^{24}$.

La solución de compromiso tomada por la Junta General el 28 de julio fue la adopción de un plan de servicios en el que, según Celina Ribechini: "se creaba la obligatoriedad en el Servicio [militar], si bien su organización se hacía en base a

22. V. DESDEVISES du DEZERT, Georges: "Las milicias vascas en el siglo XVIII", en Revista Internacional de Estudios Vascos, v. 19, no 2 (1928), pp. 225-229.

23. Cfr. VILLAVASO, C.: op. cit., Muga, p. 31.

24. Ibídem, Apéndice no 5, "Discurso-exposición de D. Simón Bernardo de Zamácola ante la Junta General de Guernica", pp. 151-187. 
la creación de un grupo de milicias provinciales, cuyos mandos debían ser todos del país" ${ }^{\prime 25}$. Dicho plan, constituido por un decálogo de artículos, tomaba como base las ordenanzas criminales redactadas por Francisco Aranguren y Sobrado en 1799, cuya severidad motivó en su momento la desaprobación de Urquijo ${ }^{26}$. Luis de Guezala recuerda que el plan recogía otros aspectos molestos para la población, como la obligatoriedad del uniforme, la periodicidad de los alardes o la creación de compañías permanentemente activas, con el propósito de que en tiempos de paz se dedicaran a la persecución de los malhechores ${ }^{27}$.

A falta de que les fuera comunicado, los rumores que corrieron entre los vizcaínos sobre el plan militar concitaron un estado de opinión contrario al mismo. Murga escribe que en muchos pueblos de Vizcaya "se levantaba el grito descompasadamente contra el plan" ${ }^{28}$. La crispación ya era patente el día 12 de agosto, cuando tomó posesión el nuevo gobierno del Señorío en la anteiglesia de Abando. En Gordexola los vecinos Ilegaron a desautorizar públicamente a sus apoderados por haber aprobado el plan militar. El 16 el apoderado de la anteiglesia de Begoña fue retenido porque se negaba a explicar las condiciones del plan aprobado. Posteriormente un grupo buscó a Zamacola en Abando, al grito de "Muera D. Simón de Zamacola: muera el corregidor: muera el consultor: mueran los diputados generales; y mueran todos los Zamacolistas" ${ }^{29}$. El 17 los begoñeses proclamaron ante una imagen de Nuestra Señora de Begoña la intención de manifestar al rey su desaprobación del plan y prender a quienes lo dispusieron para entregarlos a la justicia. Los amotinados o matxines ${ }^{30}$ emplea- $^{\prime \prime}$ ban las formas habituales en las revueltas populares. La "Zamacolada", bautizada así por Zamacola, daba comienzo ${ }^{31}$.

Los acontecimientos se precipitaron a partir de entonces. José Domingo de Mazarredo $^{32}$, cuenta que esa noche, al acabar la acostumbrada partida de tresi-

25. Cfr. RIBECHINI, Celina: op. cit., p. 65.

26. En una real orden del 6 de noviembre de 1799 Urquijo recomendó algunas modificaciones, como la privación a los reos de medios legítimos de defensa para abreviar los trámites judiciales o la estipulación de la pena capital para un número diverso de delitos. AHDB, Administrativo, J0037/070

27. V. GUEZALA, Luis de: op. cit., p. 107.

28. Cfr. VILLAVASO, C. de: op. cit., Muga, p. 34.

29. Cfr. ZAMACOLA, J. A.: op. cit., p. 185. Finalmente, Zamacola consiguió huir a su localidad natal, Dima.

30. Las revueltas populares que tuvieron lugar en las Vascongadas durante los siglos XVIIXIX se conocen como matxinadas. El nombre parece derivar de San Martín (Matxin), el patrón de los ferrones medievales, que acabaron siendo identificados por el nombre del santo. Por extensión, matxin acabaría personificando al pueblo vasco. V. EGAÑA, Iñaki: Diccionario histórico-político de Euskal-Herria, Tafalla, Txalaparta, 1996, p. 513.

31. V. GUEZALA, L.: op. cit., pp. 115-116; RIBECHINI, C.: op. cit., pp. 69-70.

32. José Domingo de Mazarredo (1745-1812), reconocido como el mejor marino español de la segunda mitad del siglo XVIII, mantuvo una estrecha amistad con su paisano Urquijo, fraguada al paso de este último por el ministerio. A partir de entonces el destino de ambos se unió. 
Ilo, sus compañeros de juego le comentaron que la anteiglesia de Begoña había mandado al ayuntamiento de Bilbao una comisión compuesta de gente armada para negociar con la Diputación, solicitando la suspensión del plan militar y reclamando las armas que tenía en el depósito del Señorío, sito en Abando. Mazarredo no pudo dormir durante aquella noche, desvelado por el amenazante repiqueteo de campanas procedente de Begoña, Abando, Deusto y Barakaldo, que llamaban a sus vecinos a asamblea ${ }^{33}$. Seguramente su buen amigo Urquijo también quedó insomne.

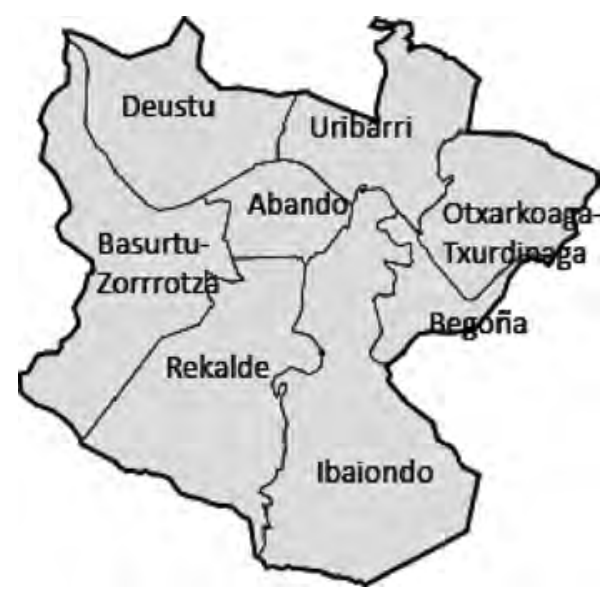

GRÁfICO 1. Mapa actual de los distritos de Bilbao. Durante los siglos XIX y XX la ciudad de Bilbao, que originariamente era el distrito de Ibaiondo (Casco Viejo) fue anexionándose el terreno de las anteiglesias que la rodeaban.

Tanta preocupación tenía su fundamento. Al día siguiente algunos centenares de hombres armados con fusiles y bayonetas penetraron en Bilbao e irrumpieron en la Diputación, llevándose consigo al corregidor y a los diputados, algunos de los cuales eran destacados miembros de la facción zamacolista ${ }^{34}$ y habían participado en las comisiones del Puerto de la Paz y el plan militar. Fueron conduci-

Cuando Urquijo cayó, Mazarredo fue apartado de su puesto como plenipotenciario en París. Los dos compartieron retiro en Bilbao, mediaron en los tumultos de la "Zamacolada" y sufrieron como consecuencia un ignominioso destierro. Posteriormente ambos colaborarían con la monarquía josefina. Sobre Mazarredo véase BARBUDO DUARTE, Enrique: D. José de Mazarredo, Teniente General de la Real Armada, Las Rozas-Madrid, Fragata, 2008.

33. V. VILLAVASO, C.: op. cit., Mazarredo, pp. 227-228. El arsenal era el sitio donde se depositaban las armas de las milicias vizcaínas, que se encontraba en Abando.

34. Curiosamente también apresaron a Pedro de Abendaño, destacado anti-zamacolista. 
dos a la casa consistorial de Abando. Desde el ayuntamiento de Bilbao, aprovechando su condición anti-zamacolista, enviaron algunos ediles a las anteiglesias de Abando y Begoña para calmar los ánimos, entre ellos José María de Murga. Una vez allí apenas se les dejaría hablar, pues lo que querían los matxines era que sus reivindicaciones fuesen escuchadas. Estas eran la anulación del plan y la ratificación de la misma en unas nuevas Juntas generales que habrían de ser convocadas en pocos días, según un papel que remitieron los matxines de Begoña ${ }^{35}$.

Al tiempo que los ediles regresaban con las manos vacías, una comitiva armada de unos cien hombres encabezada por el licenciado José Javier de Goitia -que, por su condición de letrado, había sido reclamado por los amotinados para que defendiera sus reclamaciones con los diputados- se presentó en Bilbao. Goitia había arrancado de los matxines la concesión de que se presentara otro mediador, con un perfil lo suficientemente discreto como para no levantar recelos. A eso de la una se presentaban en casa de Mazarredo el propio Goitia con un fiel de Abando y le ponían al corriente de la situación. Insistieron en que el peligro era inminente pues, a pesar de que el corregidor y los diputados habían firmado sendos decretos para la anulación del plan y la convocatoria de nuevas Juntas, su vida continuaba en peligro. Mazarredo se avino a partir hacia Abando y reclamó el acompañamiento de Mariano Luis de Urquijo, porque tenía gran capacidad retórica y poseía una casa donde se podrían resguardar los presos si se los daban en custodia. Este salió con su padre, Francisco Policarpo. Los tres ilustres personajes, dos de ellos antiguos diputados del Señorío ${ }^{36}$, se unieron a la partida de hombres armados y, conformando un extraño cortejo, atravesaron el puente de madera que Ilevaba a Abando "sin que se supiera si para bien ó para mal, y dando que temer los ejemplos de Avendaño y de la Diputación" ${ }^{\prime 37}$.

A la una y media alcanzaron el ayuntamiento de Abando. En la sala del y graderío del edificio había, según relata Mazarredo, más de doscientos matxines que a duras penas consiguieron apartarse para abrir paso a los recién llegados a la cabecera donde, tras una mesa, arrinconados, se encontraban el corregidor y los diputados presos junto con una custodia de doce a dieciséis guardianes. Los tres ilustres se subieron a la mesa y Urquijo trató de hablar, pero resultó imposible dado el bullicio existente en la sala. Entonces exhortó a los matxines a que saliera y permitieran que les hablaran desde el balcón ${ }^{38}$. Murga, que regresó a Abando a eso de las dos, narra las dificultades que provocó el desalojo pues "unos no querían obedecer y otros querían obligarles a que obedecieran. Todos estaban bien pertrechados de fusiles y bayonetas pero reñían a

35. V. GUESALA, L.: op. cit., pp. 124-127; VILLAVASO, C.: op. cit., Muga, p. 40-45.

36. Se trata de los dos Urquijo, Francisco Policarpo y Mariano Luis, que fueron nombrados como diputados el 14-VII-1800.

37. Cfr. VILLAVASO, C.: op. cit., Muga, p. 45.

38. Ibídem. Mazarredo, pp. 230-231. 
puñadas y torniscones" ${ }^{\prime 39}$. Hubo algunos matxines que, pese a los ruegos, permanecieron en el interior del ayuntamiento.

Mariano Luis de Urquijo y Mazarredo hablaron desde el balcón para la abigarrada muchedumbre ${ }^{40}$ que les escuchaba desde abajo. El público no permitió que hablara el corregidor ni ninguno de los diputados presos. Fueron dos horas de alocución repletas de insultos y amenazas. Urquijo leyó el nuevo decreto compuesto por la Diputación, al que los matxines completaron a voz en grito con nuevas condiciones que hubo que añadir al margen del documento. Principalmente lo que pretendían era que las Juntas se celebrasen en Albia ${ }^{41}$ o en Begoña, y que se destituyera al corregidor Pereira, quien "todo trémulo" comentó por dos veces que estaba conforme. Urquijo se negó a una y otra proposición, recordándoles que iban contra el fuero y contra el rey ${ }^{42}$.

Aprovechando un momento de sosiego, Urquijo pidió la libertad de los detenidos, provocando entre los matxines un enorme revuelo. Urquijo trató por todos los medios de mantener la calma asegurando que salían garantes de que no huyeran, alojándoles en sus casas de Bilbao, pero eso no impidió que la masa asaltara el ayuntamiento. Se desató entonces una batalla campal, de la que Urquijo nos ha dejado un vivo relato:

"Apenas nos vimos en el campo con ellos, cuando las mujeres, que son las peores en todas las conmociones, principiaron a insultar a los hombres porque los dejaban llevar, y entonces ellos, agolpándose en torno sobre nosotros, nos los arrancaron [los presos] de los brazos; y por dos veces, a no haber hurtado el cuerpo, me hubieran traspasado con las bayonetas. Seria[n] menester infinitos pliegos para poder pintar nuestra situación en aquella hora, y nunca podría hacerse tan mágicamente que diese siquiera la menor idea de nuestro riesgo, después de cinco horas de gritar, ro-deados de bayonetas por todas partes, al sol ardiente en un mes de agosto entre el polvo, entre la opresión de tanta multitud bárbara y furiosa, que todo querían, sin saber lo que querían ni poderles entender; y así nos condujeron hasta el calabozo de la misma casa consistorial, en que pretendían volver a meter de nuevo al corregidor y Diputación. Yo no podré jamás alabar bastante el trabajo y tesón de Dn. José de Mazarredo, y de mi padre, ni decir los empellones y golpes que llevamos hasta que volviéndoles a hablar de nuevo, diciéndoles que escribiríamos al rey (lenguaje que es necesario usar para con ellos), a fin de que los perdonase del primer atentado, pero que no se

39. Cfr. VILLAVASO, C.: op. cit., Muga, p. 46.

40. Urquijo contabilizó "miles de hombres armados", la mayor parte de los cuales ya estarían congregados en torno al edificio. Muchos de ellos no eran de Abando, según observó la Diputación presa. AHN, Consejos, leg. 51535, Interrogatorio a Mariano Luis de Urquijo, f. 26. Mazarredo (p. 231) habla de más de dos mil personas, un quinto de las cuales serían mujeres.

41. Un pequeño lugar colindante con Abando.

42. AHN, Consejos, leg. 51535, Interrogatorio a Mariano Luis de Urquijo, ff. 26-27. 
podría conseguir esto si retenían al corregidor y diputados; y en fin, invocando el nombre de S. M., que siempre veneraban y vitoreaban; y ayudados de algunos hombres provectos de la anteiglesia que se habían persuadido de nuestra razón, y de los curas, logramos volver a sacar, agarrados de nuestro brazo el corregidor y diputados. Mas al pasar el barco para Bilbao hubo otro choque sobre querer volvérselos a llevar, y habiendo nosotros hecho que se metiesen apresuradamente en él el corregidor y diputados, cargó tanta gente armada que el barco balanceaba, y en aquel momento creí firmemente morir ahogado. Llegamos en fin a la orilla con mil trabajos, y sin poder los remeros tener siquiera un pequeño espacio para bogar, y apenas desembarcados todos, mojados, cuando la muchedumbre armada que venía con nosotros, y otra que había pasado en diferentes barcos al mismo tiempo, insistió de nuevo, encarándose conmigo y llenándome de improperios, para arrancarme al corregidor y uno de los dos diputados generales (que no hago memoria quién sea), a quienes llevaba a cada yo agarrado de cada brazo. Dije que embarazaría con mi espada al primero que me llegase a tocar, ni intentase tal aunque me hiciesen después mil pedazos, que eran hombres sin palabra y que qué querían después de lo convenido. El corregidor, en un tono que verdaderamente podía mover a compasión, les preguntó que qué querían de él, y ellos le pidieron que se les suministrase la pólvora y municiones que había en la villa de Bilbao. [...] Este, luego que oyó la petición de los conmovidos sobre pólvora, volvió la cabeza a todas partes para ver si encontraba alguno a quien mandársela entregar, y como viese a dichos dos regidores [Florentino Sarachaga y José María de Murga] cerca de sí, les ordenó que se la diesen. Hice yo una seña para que no se la entregasen, y no sé si la entendieron; solo me acuerdo que uno de los citados regidores dijo que había muy poca; que entonces los conmovidos empezaron a empellones con nosotros de nuevo, como queriendo obligarnos a retroceder y a reembarcarnos para volverse a llevar al corregidor y diputados a Abando: que a mí me pegaron tal golpe en el pecho que aún me resiento de él: y que viendo todo el corregidor, dijo, volviéndose a los regidores de la Villa: «Señores, por Dios déseles lo que haya», y ellos entonces marcharon rodeados de los conmovidos a entregársela $[\ldots]^{\prime \prime 43}$.

Murga se ofreció a ir al ayuntamiento para dejar recado del ofrecimiento de pólvora hecho por el corregidor. Allí marchó junto con su compañero Florentino $-\mathrm{O}$ Florencio- de Sarachaga ${ }^{44}$ y la partida de hombres armados. El resto fue a casa de Urquijo para reponerse del susto ${ }^{45}$. Pero los desvelos no terminaron ahí. Nada más entrar en su residencia Urquijo se dio cuenta de que faltaba su

43. AHN, Consejos, leg. 51535, pieza 12, ff. 28-29.

44. Según Luis de Guezala, Sarachaga, aparte de pertenecer a una de las familias más antiguas y acaudaladas de la Villa, era pariente cercano y amigo íntimo de Urquijo. V. GUEZALA, L: op. cit., p. 120, nota 442.

45. V. VILLAVASO, C.: op. cit., Muga, p. 49. 
padre, Francisco Policarpo. Le contaron entonces que se había entretenido queriendo salvar al escribano José Antonio de Oleaga y a Pedro de Abendaño, cuyo anciano cuerpo tuvo que soportar tantos golpes que a los dos días recibió la extremaunción ${ }^{46}$. Sobre las cinco de la tarde, a pesar de no haber probado bocado, encontrarse molido por los golpes y chorreando de sudor, Urquijo partió en busca de su padre. Por fortuna se lo encontró de camino, y le dijo, sonriente, que los habían libertado a todos a cambio de firmar un papel donde avalaba que los arrestados respetarían los fueros de Vizcaya.

Refugiados en casa de Urquijo, y mientras la Diputación daba cuenta de sus sinsabores, se fueron presentando, desde el atardecer hasta las 10 de la noche, varias partidas de hombres armados que exigían que el corregidor y los diputados se desplazasen a sus pueblos a dar cuenta de la conducta que observaron en las pasadas Juntas generales, tal y como habían hecho en Abando. Como recordaría Mazarredo, si abandonaban el asilo de la casa de Urquijo todo era perdido $^{47}$, por lo que tuvieron que emplear una gran dosis de paciencia en convencer a los matxines de que las personas a quienes custodiaban no se iban a mover de allí. Especialmente complicado fue hacerse entender con los de Deusto, que desoyeron las razones de su representante y golpearon a todo el que pillaron. Tan delicada era la situación que, al pretender salir Urquijo para ir a Deusto a calmar los ánimos, los diputados y el corregidor le imploraron que no lo hiciera, pues él era el fiador de sus vidas y si se iba temían que se los llevasen de nuevo. Finalmente marchó a dicha anteiglesia Francisco Policarpo, consiguiendo aplacar el furor y que pusieran en libertad a todos los detenidos.

Durante tres días con sus noches el corregidor y los diputados permanecieron en casa de Urquijo ${ }^{48}$. Nuestro protagonista recuerda que en todo este tiempo no pudo salir ni descansar, pues continuamente estaba alerta a los toques de campana de los pueblos vecinos y las comisiones armadas que llegaban hasta su casa y le amenazaban con quemar Bilbao si no entregaba al corregidor y la Diputación. El sitio se había convertido en un lugar seguro para todo aquel que estuviera vinculado a la facción zamacolista ${ }^{49}$, mientras los propietarios del piso reprochaban a Urquijo que por las responsabilidades que estaba contrayendo el edificio terminaría siendo pasto de las Ilamas.

46. Finalmente no moriría hasta cuatro años más tarde, el 22-VII-1808. AHEB-BEA, Libro de defunciones 1800-1886, f. 1 a $\mathrm{v}^{\mathrm{o}}$

47. V. VILLAVASO, C.: op. cit., Mazarredo, p. 232.

48. Salvo el diputado Pedro Jiménez Bretón, que dormía en casa de Mazarredo. Ibídem, p. 232.

49. Solo a una persona sacaron de la casa de Urquijo, José Antonio de Ibarra, procurador bilbaíno, a quien se llevaron unos vecinos de Begoña para que presentara en esta anteiglesia unos libros de cuentas que tenía. Fueron el corregidor y los diputados quienes, según Urquijo (f. 31 ), insistieron para que se lo llevaran por miedo a que a ellos les sucediera lo mismo. 
En el intervalo se acercó Goitia por la casa y habló con el corregidor, mostrándole un papel que contenía las peticiones de los matxines de Abando para las Juntas generales. Estos le habían amenazado con cortarle la cabeza si no las conseguía, pero él no se atrevía a tomar el poder para ello. El corregidor Pereira le contestó que "hiciese las peticiones tal cual querían, pues al cabo todo había de ser nulo". Goitia se dirigió entonces a Urquijo y le dijo que los vecinos de Abando pretendían que tanto él como Mazarredo pidiesen a la Junta que les nombrase diputados generales honorarios. La negativa fue categórica: "contestele delante del corregidor y diputados que se guardase muy bien de eso, y que solo la ignorancia podía salvar aquel pueblo de tal disparate, pues que eran despreciables tales cosas para personajes como nosotros, condecorados, por la bondad de S. M., con los más altos honores: Que si Vizcaya, en memoria de que habíamos procurado apaciguarla, nos daba las gracias, lo recibiríamos como un efecto de su gratitud, pero que siempre mirábamos como objeto en estas fatigas el servicio de $\mathrm{S}$. M., libertando sus pueblos de una ruina y a la humanidad de mil desastres ${ }^{\prime 50}$.

No solo los Urquijo y Mazarredo ejercieron como pacificadores. El ayuntamiento de Bilbao prosiguió con la labor apaciguadora que el 17 le encomendara la Diputación, aunque con escasos resultados. Una partida de matxines secuestró al secretario de la Villa y le obligaron a sacar del correo las cartas de la Diputación y de otras personas para llevarlas a leer a Abando, por si en ellas hallaban nuevos detalles del plan militar. El cabildo determinó que José de Basarrate y Murga partiesen a Abando con un oficio en el que rogaba que las cartas no se abrieran, sino que se entregaran cerradas a Mariano Luis de Urquijo. Solo pudieron entregárselo al fiel de la Villa, quien prometió dar cuenta de la solicitud ${ }^{51}$.

A todo esto, en la mañana del día 19 se fueron eligiendo en algunas localidades los primeros apoderados para las Juntas generales, convocadas para el día 22. Como recuerda Murga, por entonces se propaló el rumor de que toda Vizcaya, por odio al plan, perseguía a quienes habían sido sus apoderados en las últimas Juntas; una noticia exagerada pero que, entonces, parecía del todo creíble. Murga creía que la celebración de nuevas Juntas era "el único medio para descansar por unos días de los continuos sustos y sobresaltos que pasábamos". No podía olvidar, sin embargo, que estas Juntas tendrían lugar con parte del país levantada en armas y estaba covencido de que los apoderados carecerían de libertad a la hora de decidir. A esta idea le oponían la de que era probable que los matxines dejaran las armas en cuanto se congregasen las Juntas y obedecieran sumisamente los decretos ${ }^{52}$, reconduciéndose de esta forma la matxinada. Esta última era la posición de Urquijo, que sostenía que el motín se hallaba

50. AHN, Consejos, leg. 51535, pieza 12, f. 31.

51. V. VILLAVASO, C.: op. cit., Murga, pp. 51-52.

52. Ibídem, pp. 53-54. 
localizado en un área cercana a Bilbao: "Vizcaya no era un pueblo, ni tres, ni cuatro, y que pues por su gobierno tenía su representación general en las Juntas, a ella expusiesen lo que quisiesen y aguardasen sus decisiones respetando a sus magistrados y estando quietos" ${ }^{\prime \prime 3}$.

Ese día llegó a casa de Urquijo, Diego Antonio de Basaguren, secretario de justicia del ayuntamiento de Bilbao. A Basaguren le había conferido el ayuntamiento de Bilbao una misión muy delicada. Habían llegado rumores de que, por influjo de Zamacola, Dima y otros pueblos de la merindad de Arratia habían tomado las armas para ir a Bilbao a combatir a los matxines ${ }^{54}$. Si ambos sectores entraban en combate, el Señorío se convertiría en escenario de una guerra civil vizcaína. Parece, sin embargo, que se trataba de una añagaza para impedir la celebración de nuevas Juntas. La Diputación fue consultada al respecto y elaboró un bando en el que condenaba por traición a la pena de muerte a todo aquel que fuese contra Bilbao o Begoña. La convocatoria de Juntas, por otra parte, seguía adelante ${ }^{55}$. Basaguren se encargó de hacerlo comunicar.

Urquijo no controlaba a la gente que aquellos días entraba y salía por su casa, pues la había dejado como una especie de sede provisional para la Diputación. Fue el corregidor el que le presentó a Basaguren, rogándole que le diesen de comer pues debía marchar a Dima con una providencia suya. Al rato se presentó de forma un tanto abrupta en el comedor el regidor del ayuntamiento de Bilbao José Javier de Gortázar con unos veinticuatro hombres ${ }^{56}$ y manifestó "que venían todos aquellos hombres porque no querían ir menos". Era la escolta que había de acompañar a Basaguren. Este replicó que no quería ir con tanta gente. El corregidor propuso encargar la comisión a otro escribano. Los hombres que acompañaban a Gortazar, matxines, comenzaron a alborotarse, por lo que el corregidor Pereira, temeroso de nuevos disturbios, inquirió a Basaguren la razón de que no quisiera partir. Basaguren repitió la misma respuesta que antes. Tanto el corregidor como Urquijo y los diputados le recordaron el compromiso que tenía y las nefastas consecuencias que sobrevendrían si no lo cumplían. Basaguren pidió hablar con Urquijo a solas. En un pasillo se sinceró:

"«Señor: yo soy hombre de bien, debo toda mi fortuna a Zamacola». Creo que me añadió que aún tenía parentesco con él (bien que de esto no estoy [tan] seguro como de lo demás). «¿Cómo quiere Vm. que yo vaya a prenderle? ». Contestele: «ni yo quiero que tal suceda; me gusta mucho su hombría de bien de bien (sic) de Vm., y su modo de pensar. Tengo prue-

53. AHN, Consejos, leg. 51535, Interrogatorio a Mariano Luis de Urquijo, f. 33.

54. V. GUEZALA, L.: op. cit., p. 133.

55. El bando se encuentra reproducido en GUIARD, T.: op. cit., pp. 40-41.

56. De las anteiglesias de Deusto, Abando y Begoña. Cada una proporcionaba seis hombres armados y dos desarmados. V. GUEZALA, L: op. cit., p. 136. 
bas desde el año 95 de la de aquel, y yo le estimo; no se trata de prenderle, según parece, sino de ir Vm. con un exhorto del corregidor, según acabo de oír, para que en aquellos pueblos no hayan armas contra estos alborotados; y en el caso de que se tratara de prenderle por estos hombres que van con $\mathrm{Vm}$., lo primero son pocos para los que él tiene allí a su devoción, y lo segundo, que aunque todos le abandonasen en su País, que no lo creo, Vm. va a caballo, estos a pie, y algunos bebidos. Antes que lleguen a Dima serán ya muy pocos y $\mathrm{Vm}$. se adelanta y avisa: Con que vaya $\mathrm{Vm}$., que es mejor que otro, y no nos exponga, por Dios, por una friolera, a que vuelvan estos hombres a sus pueblos diciendo que los han engañado, toquen las campanas, se vengan aquí en multitud, perzca el corregidor, y la diputación, y yo, y todos, y haya mil desastres»" ${ }^{57}$.

El corregidor se les unió en la conversación e imploró a Basaguren: "por Dios, vaya $V m$.: haga $V m$. esto por mí: yo se lo pido a $V m$., vea $V m$. que es de nosotros". Urquijo añadió que si se iban y los matxines volvían alborotados, el propio Basaguren se convertiría en su primera víctima. Con Basaguren impresionado, regresaron al comedor, donde los matxines se encararon con Urquijo para inquirirle de qué habían estado hablando, pensando que tramaban alguna maniobra para evitar el arresto de Zamacola. Urquijo solo les contó que Basaguren temía que le maltrataran y estos lanzaron graves amenazas por si se producía alguna sorpresa. Hubo un enfrentamiento entre un matxin y Urquijo, quien en su relato se envanece de haber defendido a Zamacola ante los amotinados "cual si fuera un hermano mío y lleno de furor". Aún recuerda que pudo intercambiar un guiño de complicidad a Basaguren para que se acordara de lo que habían hablado en el pasillo sobre la forma de evitar la detención de Zamacola.

Basaguren partió con su comitiva. En Galdakao sufrieron un incidente que provocó la huida de los componentes menos levantiscos, reforzando así la convicción de apresar a Zamacola, pese al criterio del secretario de justicia bilbaíno. El grupo llegó a Dima a las once de la noche del día 20. Esa tarde otra comisión intentó detener a Zamacola esgrimiendo un oficio firmado por los fieles de Begoña, pero los dimostarras se opusieron con contundencia. La partida de Basaguren, compuesta por veintidós hombres, tuvo un enfrentamiento al llegar a la localidad pero consiguió mostrar el bando de la Diputación. Su lectura posibilitó que los vecinos entregaran las armas y se pudiese registrar la casa de Zamacola. Sobre este, que hasta entonces había permanecido allí, ocupado en escribir a a diferentes pueblos para rebatir los argumentos de los matxines, no se halló rastro. Había huido junto con un sobrino y la persona en la que se había pensando como comandante de las nuevas tropas vizcaínas, José María

57. AHN, Consejos, leg. 51535, pieza 12, ff. 34-35. 
de Orbe. Basaguren, aprovechando la confusión, también se escapó y terminó uniéndoseles ${ }^{58}$.

Las noticias que Ilegaron a Bilbao fueron confusas. Se decía que la partida había sido hecha presa en Dima, que Basaguren había escapado, que los pueblos de Arratia marchaban hacia la Villa, etc. La gente de Abando y Begoña que había traído la noticia solicitaba al ayuntamiento de Bilbao que se preparara para hacerles frente. La amenaza no solo provenía de los matxines, sino ahora también de aquellos que querían hacerles frente con las armas. A quienes se hallaban congregados en torno al ayuntamiento, se les llamó a la calma y se les pidió que esperasen que los rumores fuesen confirmados. Murga pasó con un compañero suyo a casa de Urquijo para exponer a la Diputación la gravedad de la situación. Asustados por el ruido de campanas en Abando y Begoña, decidieron que cada pueblo enviara ochenta hombres a Bilbao, eligiéndolos entre las personas de mayor confianza, y que se pusiesen a disposición de dos regidores, los cuales responderían ante la Diputación. Poco a poco, como nada ocurría, los ánimos se fueron calmando y los apoderados de Bilbao estuvieron listos para partir a Gernika ${ }^{59}$.

La salida de la Diputación para las Juntas no exoneró a los Urquijo y Mazarredo de las responsabilidades que habían contraído con la gente apresada por los matxines. Mariano Luis de Urquijo se trasladó a Abando para conseguir la libertad del consultor del Señorío Francisco Antonio de Aranguren, que al inicio de los desórdenes había sido hecho preso. Corriendo el riesgo de verse también retenido, consiguió que las mujeres fueran sacadas de la cárcel ${ }^{60}$ y que los hombres fuesen trasladados a la prisión del Señorío, donde era de esperar que estuvieran más seguros que custodiados por los matxines. La situación no era demasiado alentadora, a pesar de que las Juntas generales se estaban celebrando con normalidad. Como recalca Luis de Guezala, desde un plano formal cumplían con todos los requisitos para ser válidas, incluida la convocatoria extraordinaria. Todos los pueblos vizcaínos eligieron apoderados y junteros; aquellos que se habían rebelado disponían además de correos de a pie que servían de canal de comunicación para que los vecinos conocieran los decretos que eran aprobados y enviaran instrucciones ${ }^{61}$.

58. V. GUEZALA, L.: op. cit., pp. 136 y 140.

59. V. VILLAVASO, C.: op. cit., Murga, pp. 54-57.

60. Entre ellas se encontraba María del Carmen Elejalde, esposa del ilustrado Vicente González Arnao, que se hallaba embarazada. González Arnao y su mujer se encontraban en Abando durante la fallida toma de posesión del gobierno del Señorío por la calidad de este de asesor de Zamacola en el asunto del Puerto de la Paz. Junto con otras personas intentaron huir de Abando tras el estallido de la matxinada sin conseguirlo. V. RIBECHINI, C.: op. cit., p. 76.

61. V. GUEZALA, L.: op. cit., pp. 153 y 158-159. Estamos con él cuando les niega un presunto carácter revolucionario: la única ruptura fue con la conducta que observaron los apoderados en las anteriores Juntas. 
El diputado José Agustín Ibáñez de la Rentería, destacado miembro de la facción zamacolista, huyó de Gernika la noche del 22 y marchó a Donostia. En esta ciudad permaneció treinta y dos días, durante los cuales intercambió correspondencia con Zamacola ${ }^{62}$. Rentería había sido uno de los diputados que permanecieron custodiados por Urquijo, y en una carta dirigida a este a finales de septiembre justificó su evasión amparándose en el "modo irregular" con que se procedió con él el día de apertura de Juntas. Este "modo irregular" fueron las críticas que vertieron los junteros contra la facción de Zamacola tras la lectura pública del plan militar ${ }^{63}$. La deserción de Rentería puso a Urquijo en apuros al achacarle los matxines tener parte de responsabilidad en la misma ${ }^{64}$. En esta ocasión Urquijo tuvo que ser salvado por su amigo Mazarredo, junto con los fieles y el cura de Begoña.

Durante el tiempo que duraron las Juntas, del 22 al 30 de agosto, Urquijo recibió diariamente correspondencia del corregidor y los diputados. El 27 este le informaba:

"que los de Begoña, no contentos con que los baúles (habla de los de Zamacola ${ }^{65}$ se depositasen en Guernica, guardando los dos de ellos y otros de la confianza del alcalde, se empeñaban en que había de remitirlos a Bilbao: que él no podía exponer una cosa que podía ser de tanta importancia $y$, en que acaso hubiera papeles interesantes al estado, para que se trajesen a un pueblo en donde acababan de suceder tales desórdenes, sin que su ayuntamiento hubiese podido impedirlos; y que así viese cómo contener y hacer cargo de ello a los de Begoña, para que desistiesen de tal llevada de cofres a Bilbao" ${ }^{\prime 66}$.

Como Urquijo había perdido su predicamento con los vecinos de Begoña, consultó con su amigo Mazarredo y entre ambos decidieron llamar a los fieles de la anteiglesia, para ver si por su medio podían hacer desistir a los matxines de la población de sus propósitos. Estos Ilegaron a casa de Urquijo con más

62. V. GUEZALA, L.: op. cit., p. 90.

63. AHN, Consejos, leg. 51535, pieza 12, Rentería a Urquijo. San Sebastián, 21-IX-1804, f. 7. Sobre el ambiente en Gernika v. VILLAVASO, C.: op. cit., Murga, p. 60

64. V. RIBECHINI, C.: op. cit., p. 80.

65. En Gernika corrió el día 24 la voz de que Zamacola había ocultado en huerta suya de Dima un tesoro de más de cincuenta libras de oro y que en la casa de otro vecino de la anteiglesia había doce baúles con papeles comprometedores sobe el plan militar. El tesoro no se halló, pero sí los baúles, que fueron traídos a Gernika convenientemente sellados y puestos a disposición del corregidor. Pese a los intentos de otros junteros por abrirlos, el corregidor se negó a quitar el precinto de los sellos, situando a este en el punto de mira por su conocida amistad con Zamacola y sembrando grandes sospechas sobre lo que contendrían los papeles. V. GUEZALA, L.: op. cit., pp. 151-152; VILLAVASO, C.: op. cit., p. 64.

66. AHN, Consejos, leg. 51535, pieza 12, f. 37. 
gente, excusándose en la conmoción que había provocado entre los begoñeses el descubrimiento de los baúles, obligándoles a ir al encuentro con más compañía y teniendo además que ir por atajos, para que un posible no retraso no despertara aún más recelos. Urquijo y Mazarredo les leyeron la carta del corregidor. Los fieles alegaron que ellos no se atrevían a pedir a sus vecinos que cejasen en el empeño de ver el contenido de los baúles. Urquijo replicó que entonces pidieran a la Junta que se abrieran en su presencia, pues ella juzgaría lo que creyera oportuno, pero se le contestó que los alborotados tampoco consentirían esa propuesta. Al final Urquijo tuvo que ceder, enfadado, a que transmitieran a los matxines de parte suya y de Mazarredo que el contenido de los baúles solo se mostraría si accedía a ello la Junta, y que se debían someter a los dictados de esta.

Tras mucho parlamentar Urquijo se lisonjea de haber conseguido evitar que los matxines no fueran armados a Gernika en busca de los baúles. Pero los esfuerzos desplegados en aquellos días le estaban pasando factura. No pudo evitar mandarle una carta al corregidor informándole de que estaba harto de los encargos que le mandaban; que poniendo en riesgo sus vidas Mazarredo, su padre y él habían apaciguado varias conmociones y ya se respiraba alguna tranquilidad, por lo que había cesado su papel de "predicadores" y la correspondencia con la Corte sobre tales asuntos; que era impropio de sus personas meterse a aconsejar a las anteiglesias en sus pretensiones particulares, aparte de que les privaba del poco miramiento que tenían en ellas; que a pesar de lo anterior, tras la recepción de la carta del corregidor, habían hablado con los fieles de Begoña para intentar calmar la situación.

Al día siguiente tuvo lugar en Gernika una Junta "muy desabrida" a consecuencia del asunto de los baúles. Esa tarde se congreraron los Padres de la Provincia y los letrados para ver si se hallaba un medio de no alterar a los matxines y junteros que pedían la apertura y al mismo tiempo de evitar los inconvenientes que pudiera acarrear el conocimiento del contenido de los baúles ${ }^{67}$. Urquijo cuenta que ese día, mientras salía a dar un paseo, le cogió un grupo de vecinos de Begoña, dirigidos por su fiel. Provocándole a que diese razones para que no fueran a Gernika a tomar por la fuerza los cofres, Urquijo terminó perdiendo la compostura. Les gritó que aquello era un crimen contra la monarquía y que tanto él como Mazarredo y cualquier persona que se preciara de buen servidor del rey abandonarían el Señorío. La presencia del teniente corregidor obligó a los matxines a marcharse.

Esa noche Urquijo fue a casa de Mazarredo a jugar al tresillo con el general y otros personajes. Allí, a eso de las once de la noche, avisaron a los jugadores que una multitud, proveniente de las anteiglesias cercanas y del propio Bilbao,

67. V. VILLAVASO, C.: op. cit., Murga, p. 65. 
se había congregado en torno al ayuntamiento de la Villa reclamando armas con las que poder ir a Gernika a hacerse con las cofres. La primera reacción de Mazarredo, buscando la protección de su amigo, fue cerrar con llave la puerta de la casa. Pero mientras discutía con los invitados qué acción sería más correcta, llegó del ayuntamiento un recado para que contuvieran a la turba. En un principio se negaron porque aquello supondría verse expuesto a los matxines, y entendían que bastante se habían prodigado entre ellos como para que les perdieran el respeto. No obstante vino un nuevo aviso, que anunciaba que habían arrancado una de las verjas de la puerta consistorial. Urquijo se dirigó a don Felipe de Urquijo, con quien compartía la velada, y le pidió que hablase en nombre suyo y de Mazarredo a los amotinados y les Ilamara a deponer su actitud. Regresó aquel diciendo que se habían aplacado después de que el teniente del corregidor enviara a la Junta un decreto solicitando la apertura de los baúles, que sería trasladado por el tercer alcalde, Manuel Victoria de Lecea.

Nuevamente recibieron un recado. Los matxines habían vuelto a forzar la puerta y se disponían a coger los más de mil fusiles que estaban almacenados. En esta ocasión Urquijo, su padre y Mazarredo se sintieron obligados a ir a calmarlos, Ilamando en su compañía a José Benito de Zarauz, mariscal de campo, que también había pasado la velada con ellos. Abriéndose paso a duras penas entre la multitud, se quedaron dentro de ella, por creer que era la mejor forma de tranquilizar a los alborotados. Urquijo les rogó que se atuvieran a la autoridad del Señorío, reunido en Junta general, y apuntó que el motín se debía a "cuatro cabecillas", que seguramente no fuesen de Bilbao, pues la Villa había permanecido hasta entonces muy tranquila.

Entonces una voz interrumpió a el discurso: "muera ese que es tan malo como los demás". "Salga ese guapo que me quiere matar", desafió Urquijo. Cuenta que quien le encaró fue un matxin malencarado que abiertamente le acusó de ser un zamacolista y de impedir la apertura de los baúles. Entre sacar la espada y exponerse al furor de la multitud o intentar convencer mediante la palabra, Urquijo optó por lo segundo espetando:

"Yo no soy zamacolista, ni de partido alguno: Vms. conocen mi dignidad y que me desagradaría alistarme en banderas de nadie; soy un vasallo del rey, favorecido y premiado por S. M.; debo defender su causa y que se respeten sus magistrados: Los que están aquí dentro (señalando el Ayuntamiento) merecen toda consideración y toda obediencia por parte de Vms.; deben obedecerles y conformarse con lo que han mandado; soy un español, soy un vizcaíno y no quiero que el país se pierda por cuatro cabezas infelices $[\ldots]^{\prime \prime} .{ }^{68}$

68. AHN, Consejos, leg. 51535, pieza 12, f. 44. 
Poco a poco el tumulto fue serenándose por la acción de personajes decididos, como los Urquijo y Mazarredo, o como el comerciante Santiago de Laurado, cuya imponente presencia contuvo a los matxines en la puerta de la segunda sala ${ }^{69}$. Urquijo aprovechó esta calma para enviar una carta al corregidor en la que, tras contarle lo sucedido, le rogaba que meditara sobre la apertura de los baúles. La legación de Victoria de Lecea sirvió para que los baúles fuesen abiertos, pero su contenido defraudó las expectativas: solo dos o tres contenían papeles, carentes de todo interés ${ }^{70}$.

Tras la celebración de las Juntas y la posterior toma de cargos del nuevo gobierno del Señorío, que tuvo lugar el 2 de septiembre, en esta ocasión sin incidentes, Godoy anunció el envío a Vizcaya de un juez comisionado encargado de investigar los sucesos ocurridos durante la Zamacolada, Francisco Javier Durán. Las autoridades del Señorío representaron arguyendo que el territorio vizcaíno se hallaba en la más completa tranquilidad, una vez pasada la furia de los disturbios, y que los decretos aprobados en las Juntas extraordinarias eran legítimos. Dos comisionados se trasladaron a Pamplona para conseguir que el virrey anulara el envío de tropas, pero fueron detenidos. El temor era grande al estar extendida la idea de que su llegada empujaría a los matxines a coger las armas ${ }^{71}$. El 21 de septiembre penetró en Bilbao la vanguardia de las tropas reales, al mando del brigadier Benito San Juan, nombrado comandante general de Vizcaya, gobernador político y militar de Bilbao, y corregidor y presidente de la Diputación y Juntas generales ${ }^{72}$. Ese mismo se presentó también Francisco Javier Durán. El 23 Ilegó el Regimiento de Voluntarios de Navarra, comandado por Gabriel de Mendizábal. Luis de Guezala calcula en unos cuatro mil el número total de soldados desplegados en la Villa ${ }^{73}$.

Si hemos de hacer caso a sus palabras, Urquijo recibió con alegría la noticia de la entrada de tropas, a pesar de que los matxines agradecieron sus gestiones $^{74}$. Según reconoce él mismo, al inicio de la matxinada solicitó al príncipe de la Paz el envío de un ministro pesquisidor que investigase el origen de la conmoción y evaluase la veracidad de las quejas que corrían sobre el corregidor y los ministros del anterior gobierno. Además también justificaba la presencia del ejército, pues la consideraba "necesaria para imponer respeto y dar autoridad a la Justicia" y, desde un planteamiento personal, porque no se sen-

69. V. VILLAVASO, C.: op. cit., Murga, p. 66.

70. Ibídem, p. 67.

71. V. GUEZALA, L.: op. cit., pp. 168-169.

72. V. RIBECHINI, C.: op. cit., p. 93.

73. V. GUEZALA, L.: op. cit., p. 181.

74. El 3 de septiembre la asamblea municipal de Abando comisionó a sus cuatro junteros para que manifestaran a Urquijo, su padre y Mazarredo "el celo con que han mirado a este País". Ibidem, p. 169. 
tía seguro ante la proliferación de rumores sobre un nuevo levantamiento Cuando el coronel Gabriel de Mendizábal y su edecán fueron a preparar los cuarteles donde se había de albergar la tropa en la Villa, Urquijo les contó que aún "en globos la hubiera querido haber traído"75. Lo que menos pudo esperar de tales salvadores fue que portasen un auto para su salida de la Villa, así como la del teniente general Mazarredo ${ }^{76}$.

\section{El proceso}

En un escrito dirigido a Francisco Javier Durán el 23 de septiembre de 1804, tras apuntar que "la Justicia clama de males tan graves [...], cargo suyo es y propio de su Ministerio tributar tal holocausto en obsequio de la Virtud", Godoy comenta que "nada más conducente que la activa providencia acordada para la salida de los Exmos. Mazarredo y Urquijo, y no dificulto tenga efecto igual disposición con el Ilmo. [Francisco Policarpo] Urquijo [...]"77. La medida sorprende no solo en el fondo, habida cuenta los numerosos intentos que protagonizaron por calmar los ánimos de los sublevados, sino también en la forma. Mazarredo recuerda con dolor que alrededor de las doce de la noche se le informó que el brigadier Benito San Juan deseaba hablarle. Le pidió que le acompañara a casa de Urquijo, donde les comunicó que debían partir de Vascongadas para marchar a Burgos. Mazarredo pidió que le dejasen reunir un poco de dinero y señalar a su mujer donde se hallaban unos legados con cuentas corrientes. San Juan se negó en firme y Urquijo y Mazarredo partieron sin más demora a Burgos, apenas cubiertos con alguna ropa ${ }^{78}$. El 25 de septiembre se dictaba igual providencia para Francisco Policarpo de Urquijo ${ }^{79}$.

Ninguno de los afectados conocía, como era habitual en los procesos políticos, los motivos de su desgracia. Desde Burgos Urquijo dirigió una representación al príncipe de la Paz en la que, proclamando su inocencia, ponía en antecedentes a Godoy sobre la Zamacolada para probar que no había cometido ningún "paso siniestro". Su relación contenía una nada velada acusación contra Zamacola y sus satélites, a quienes achacaba el proceso que estaba sufriendo. Habíamos dejado a aquel en el apartado anterior huyendo de Dima. El 23 de septiembre, junto con Orbe, Basaguren y otros personajes, alcanzó la población navarra de Etxarri-Aranaz, donde tenía unas propiedades. En los días siguientes acudieron a su refugio otros miembros de la facción zamacolista. Zamacola tenía un secreto pero seguro canal con Gernika, donde estaban

75. AHN, Consejos, leg. 51535, pieza 12, ff. 44-45.

76. AHN, Consejos, leg. 51535.2. Bilbao, 21-IX-1804.

77. AHN, Consejos, leg. 51535.1, no 3, el príncipe de la Paz a Francisco Javier Durán, 23IX-1804. El texto se halla reproducido en RIBECHINI, C.: op. cit., pp. 22-23.

78. V. VILLAVASO, C.: op. cit., pp. 234-235.

79. AHN, Consejos, leg. 51535.2. Bilbao, 25-IX-1804. 
teniendo lugar las Juntas Generales, gracias al cual recibió la copia de una carta que Godoy había enviado a la Diputación. Escrita en respuesta a las primeras noticias recibidas sobre la Zamacolada, la misiva era una defensa del plan militar, dejando entreverlo como una contrapartida a la construcción del Puerto de Abando. La conducta observada por el partido zamacolista en las pasadas Juntas quedaría de esta forma justificada ante sus paisanos. Zamacola no dejó escapar la ocasión para hacer más copias y distribuirlas entre los fieles y alcaldes vizcaínos ${ }^{80}$.

Desde Etxarri-Aranaz los zamacolistas buscaron ganar apoyos a su causa perdida en Navarra y la Corte frente a la versión de los hechos procedente de Vizcaya. El pobre comerciante bilbaino de apellido Tobalina, que iba a tomar las aguas del balneario de Belascoain y que tuvo la mala suerte de parar en Etxarri-Aranaz coincidiendo con la estancia de Zamacola y sus acólitos, fue duramente silenciado. Tobalina había cometido la imprudencia de hablar en Etxarri de las novedades que sacudían al Señorío, responsabilizando de las mismas a Zamacola. Por su locuacidad el virrey de Navarra habría de detenerle y embargarle los bienes ${ }^{81}$. Desde luego que Simón Bernardo de Zamacola no fue un personaje cualquiera. Además de penetración y elocuencia, Zamacola tuvo un carisma excepcional, de lo que Murga se dio cuenta nada más conocerlo: "desde luego conceptué que si por ambición, ó por necesidad, ó por capricho, quería llevarse tras sí todo el país, nadie sería capaz de impedírselo" ${ }^{\text {82 }}$. Gozaba además de buen trato con la Corte, lo que sin duda facilitó sus gestiones para la habilitación del Puerto de la Paz.

Las desavenencias entre Urquijo y la facción zamacolista habían salido a la luz antes del motín, si hemos de creer al primero. Urquijo recuerda en su representación las visitas que le hicieron tanto Zamacola como Pereira para que interviniera en las gestiones sobre el Puerto de Abando, de las que ya hemos hablado. Educamente Urquijo se negó participar pero no pudo evitar convertirse en su confidente, traicionando en parte la vida de discreción que había planeado llevar en Bilbao. Urquijo contradecía esta versión cuando rememoraba a Godoy las palabras que le dirigiera el corregidor Pereira antes de estallar la Zamacolada. Aquel le intimó que el decreto sobre el plan militar iba a causar una conmoción fuerte en el Señorío y que se encontraba inquieto, a pesar de que Zamacola había enviado emisarios para prevenir los tumultos. Urquijo le preguntó entonces a qué se reducía el plan. Pereira contestó que a un alistamiento general, a lo que Urquijo replicó que "era un engaño a S. M., pues quien

80. V. GUEZALA, L.: op. cit., pp. 151-153.

81. V. RIBECHINI, C.: op. cit., pp. 82-84.

82. V. VILLAVASO, C.: op. cit., Murga, p. 8. Villavaso resaltó esta frase poniéndola en cursiva y acompañándola de una nota donde llamaba la atención sobre el juicio, por proceder de una persona imparcial y equilibrada. 
alistaba a todos no alistaba, ni disciplinaba, ninguno. Pereira convino en la afirmación pero exhibió una ciega confianza en el poder de Zamacola, quien "lo allanaría todo" y repitió la consigna de que con ello "nacía el mayor servicio posible al país" ${ }^{\prime 83}$. Urquijo sabía por tanto más de lo que tantas veces contó durante el motín a los furiosos matxines.

La representación continúa ofreciendo pistas sobre las causas del desencuentro. A lo largo del documento se trasluce que los zamacolistas pintaron la Zamacolada a la Corte como un motín que incendió el Señorío por entero, cuando Urquijo lo reducía a "algunos pueblos". Algo similar había hecho en Etxarri-Aranaz el desventurado Tobalina, al advertir que se habían levantado Bilbao y los pueblos de las inmediaciones ${ }^{84}$. Reducir la gravedad e impacto de la matxinada implicaba otorgar mayor legitimidad a la convocatoria de Juntas realizada a finales de agosto, considerando válidos los decretos emanados de la misma. Urquijo era plenamente consciente de las consecuencias, y las defendió:

"Felizmente, Señor, se cortó la cosa en tiempo, con la convocación de Juntas generales decretada por ellos también; pero si no, tal vez se habría visto, que ya que consintieron en dar las armas a los conmovidos, y acaso, sin hacer la resistencia que yo hice en el menor de los sucesos, la cosa habría tenido otro paradero" ${ }^{\prime 85}$.

Censura Urquijo en esta frase, sin nombrarlo, la conducta de Luis Marcelino Pereira. Abogado e ilustrado, Pereira fue elegido para el puesto de corregidor en 1798. Muy pronto demostró su poca idoneidad con el cargo, pues el ayuntamiento de Bilbao le denunció continuamente por vulnerar las ordenanzas. Sus simpatías hacia la facción zamacolista eran más que evidentes, teniéndosele por un miembro más de la misma ${ }^{86}$. Antes del estallido de la Zamacolada, Pereira comentaba a Urquijo "lo mal que lo trataban en Bilbao, diciéndome que con la habilitación de Abando (que entonces aún no tenía otro nombre) perdería este Pueblo su poder en el Señorío" ${ }^{\prime 87}$. Su actuación durante el motín no desmereció de la realizada con anterioridad. La imprudencia y la cobardía personal que demostró fueron recogidas en la memoria de Murga y de forma especial, como no podía ser menos, en el interrogatorio a Urquijo. Pereira fue cesado como corregidor del Señorío el 6 de septiembre, antes de que las tropas entraran en la Villa, y solicitó protección al municipio, temiendo incidentes que no tardaron en suceder ${ }^{88}$.

83. AHN, Consejos, leg. 51535, pieza 12, f. 5.

84. V. RIBECHINI, C.: op. cit., p. 82.

85. AHN, Consejos, leg. 51535, pieza 12, f. 5.

86. V. GUEZALA, L.: op. cit., pp. 74-75.

87. AHN, Consejos, leg. 51535, pieza 12, f. 5. Urquijo le contestó con elegancia que sabía de la injusticia de algunos bilbaínos, pero que Bilbao sobreviviría a la catástrofe.

88. V. GUEZALA, L.: op. cit., p. 170. 
Zamacola y Pereira aparecen en la versión que hemos manejado como los responsables de los desmanes sucedidos en la Zamacolada. En una conversación sostenida con los diputados zamacolistas Pedro Jiménez Bretón y José Agustín Ibáñez de la Rentería tras su liberación de la cárcel de Abando, estos reprocharon a Zamacola ser el responsable porque "él lo mandaba todo, y ellos no eran tales diputados generales". Además comentaron a Urquijo que entre él, el corregidor y el consultor Aranguren se dedicaron a retocar el decreto sobre el plan militar una vez concluida la Junta General:

"por el pique entre el corregidor y Zamacola sobre la prisión de un vago, pariente o protegido de este, y que obtuvo él [Zamacola] entonces una orden de suspensión ofreciendo otro mejor servicio, y levantando así a aquel inviduo" ${ }^{\prime 89}$.

Fueron además los responsables del proceso incoado a Urquijo, y aún el de su padre y Mazarredo. La presentación recoge el rumor, que según Urquijo llegó a sus oídos el 1 de septiembre, de que Zamacola había amenazado en Etxarri-Aranaz en presencia del maestre de postas de Bergara, con que "no parará hasta echarme en presidio". Rosa Navas, mujer del corregidor, también dijo que temía por su suerte y la del general Mazarredo ${ }^{90}$.

El 27 de septiembre Urquijo dirigió a Godoy la citada representación, con dos cartas de los diputados Jiménez Bretón y Rentería y otra confidencial destinada al príncipe de la Paz; todas ellas destinadas a demostrar su inocencia. El envío, que contenía graves acusaciones y pruebas considerables de los servicios prestados por Urquijo durante la Zamacolada ${ }^{91}$, causó tal impresión en Godoy que ordenó al juez comisionado Durán que investigase la participación de Urquijo. El príncipe de la Paz trataba de tranquilizar a Urquijo, aseverando que "ninguna otra [providencia] hubiera dado si en punto semejante hubiese sido la deliberación privativa de mis facultades"92.

Godoy remitió a Durán una copia de la representación y carta de Urquijo para que comenzase sus pesquisas. El 20 de enero de 1805 el juez daba por concluidas las pesquisas, tras realizar interrogatorios a Pedro Jiménez Bretón, Diego Antonio de Basaguren, Luis Marcelino Pereira, José Javier de Goitia, Rentería; Josefa de Goitia, Antonio de Ingunza, Gabriel de Brea, Ignacio Antonio de Careaga, Ignacio de Gana (?), Fernando de Acha, Vicente y Francisco de Endaya, Ramón de Loizaga, Agustín de Goyarzun, Antonio de Apraiz, Pedro Antonio de Olano, Manuel María de Aurrecoechea, Joaquina del Horno, Marcos de Carea-

89. AHN, Consejos, leg. 51535, pieza 12, ff. 4-5.

90. Ibídem, f. 2.

91. Las cartas de Jiménez Bretón y Rentería eran de agradecimiento a Urquijo por haber salvado su "libertad y vida" el día 18 en Abando.

92. Ibídem, f. 8. Texto al margen. 30-IX-1804. El cinismo de esta frase no podía ser mayor, pues el ascendiente de Godoy sobre los reyes es bien conocido. 
ga -testigos de los sucesos del día 18 en Abando-; Juan Antonio de Enderica, Andrés de Basabe, José de Gorostizaga, Juan Antonio de Videa, Juan de Amezaga y José Atanasio de Garro -testigos de los sucesos del día 26 en Begoña-; José de Zuazo, alias "Caña"; Miguel de Baraya, Antonio de Achutegui -testigos de los sucesos de Bilbao-; Francisco de Recalde; alguacil Madariaga, José Antonio Oleaga -presos en Abando-; José Antonio de Ibarra; Domingo Amezola; Eugenio López de Letona; Manuela de Capanaga; y finalmente Manuel de Oleaga ${ }^{93}$.

Las declaraciones del primer grupo de interrogados, compuesto por personajes destacados y con gran protagonismo en los hechos de la Zamacolada, no difirieron en lo fundamental la versión de Urquijo los hechos acaecidos el 18 de agosto en Abando, salvo por incluir menos detalles ${ }^{94}$. Los segundos confirman tales declaraciones, declarando que Urquijo y Mazarredo solo pretendieron calmar a los matxines, negando "que los quisiesen llevar por soldados con casacas ni atados por cuerdas ${ }^{\prime \prime 95}$. Durán intercala seguidamente en el auto el testimonio de Jiménez Bretón sobre el episodio ocurrido entre Urquijo y Basaguren: "le dijo el señor Urquijo que viese lo que hacía, porque de no acompañar a aquellos hombres (habla de los amotinados), pedirían por él aquella noche; no podría menos que entregarle y le matarían". Recuerda además Jiménez Bretón que dijo a quienes iban a acompañar al escribano:

"que cuidasen de dicho secretario [Basaguren], le tratasen bien sin hacerle la menor exortación, porque si no les abadonaría: Que no disparasen arma ni le dejasen hablar, sino en su presencia y en voz clara: Que no pudiesen decir más que lo que contenía el bando: Que en el caso de que se quedasen a dormir en alguna casa del camino no le dejasen solo y durmiesen dos a lo más en su compañía para que no pudiese hablar con nadie: Que los batidores dejasen a los armados que hallasen en el camino, que el secretario Basaguren venía a hacer saber el bando, y estuviesen quietos: Que este, manifestando de lejos el papel, pasase a notificar con solos seis armados, y que los demás les siguiesen después $[\ldots]^{\prime \prime 96}$.

Se trasluce de lo citado que con estas instrucciones Urquijo pretendía evitar el choque armado entre los matxines y los vecinos de Dima. La testificación de Basaguren añada más detalles al suceso. Según la conversación tuvo lugar en el gabinete -en vez de en un pasillo, como relata Urquijo-, en presencia de José Antonio Romarate ${ }^{97}$ y otros. Urquijo y sus invitados comentaban que Zamacola

93. AHN, Consejos, leg. 51535, pieza 12, f. 9.

94. Ibídem, ff. 10-11.

95. Ibídem, f. 12.

96. Ibídem, ff. 12-13.

97. El encartado Romarate pertenecía a una de las familias más importantes del Señorío, siendo un destacado personaje tanto en los negocios como en el Señorío. V. GUEZALA, L: op. cit., p. 62, nota 190 . 
no podría resistir más y que había caído en desgracia. Hablaron de que, al parecer, los vecinos de Otxandio no opusieron ningún reparo al plan militar, a lo que Romarate adujo que "si [Basaguren] les hubiera explicado como correspondía, no se hubieran conformado". Gortázar apareció de pronto diciendo que ya estaba lista la escolta que debía a acompañar a Basaguren, pero este puso reparos a su elevado número -22 hombres, de los cuales 18 iban armados- y al hecho de que fueran matxines. Tras oír que la partida pretendía detener también a Zamacola, pidió hablar a solas con Urquijo para transmitirle sus temores a que fuera amenazado por el camino. Tanto Urquijo como Lope de Mazarredo le insistieron en que su obligación era ir a Dima, y ante tanta insistencia desistió de oponer resistencia. Basaguren reconoce que las órdenes que Urquijo dio a los matxines fueron las mismas que confirma Jiménez Bretón, aunque todavía hubo que disputar con ellos para que se comprometieran a traer vivo a Zamacola ${ }^{98}$.

Los testigos de Begoña consignaron que Francisco (sic) de Mazarredo convenció a los vecinos de Begoña para que un representante -Andrés de Basabe- fuese a casa de sus acompañantes se enteraron, como ya sabemos, de que Pereira no respondía de los efectos que tuviese la apertura de los cofres de Zamacola. En vistas de que los begoñeses se encontraban muy alterados, Urquijo dispuso un borrador de acuerdo por el que se disponía que los baules fuesen abiertos en presencia de la Junta general, que sería la encargada de inventariar su contenido. El resto de disposiciones del arreglo, que establecía que si el inventario se dilataba se encomendara a una comisión compuesta, entre otros, por apoderados de Begoña, provocó entre los vecinos de Begoña "algazara y gritería, vitoreando a dicho Exmo. Sor. Urquijo diciendo viva, viva $[\ldots]^{\prime \prime 99}$.

"Caña", es decir, José de Zuazo, hizo una curiosa testificación. Según contó a Durán se puso de acuerdo con su amo, Manuel Victoria de Lecea, para extender un papel "de lo que en la anteiglesia de Abando debía decretar para que se abriesen los baules de Zamacola". Al Ilevarlo a Abando los vecinos le quisieron meter preso, pero "Caña" solicitó que hablaran con Urquijo. Este contestó que le dejasen, aunque también manifestó que si seguía entrometiéndose, aprobaría que fuese castigado ${ }^{100}$. Urquijo señaló a Durán que "Caña" era un "majadero" al que le habían dado un papel para leer en Abando, "cuyo contenido [...] no era nada pacífico". Urquijo remitió a "Caña" a los fieles de Abando, a los cuales ya había aleccionado para que encarcelara a todo el que les fuera con solicitud de ayuntamiento para encender a los vecinos ${ }^{101}$.

98. AHN, Consejos, leg. 51535, pieza 12, ff. 13-14.

99. Ibídem, f. 15.

100. Ibídem, ff. 15-16.

101. Ibídem, f. 45. 
Baraya y Achutegui testificaron sobre las tareas de apaciguamiento de los señores Urquijo y Mazarredo en Bilbao, cuando los matxines asaltaron la armería en Bilbao ${ }^{102}$. Francisco de Recalde, junto con Juan Antonio de Enderica, declaró que algunos matxines de Begoña, especialmente Matías de Usabel -alias "Matico"-, quisieron "llevar preso[s] al cepo a los Exmos. Urquijo y Mazarredo" tras conocerse la huida de Basaguren, al entender que eran responsables de la conducta de la Diputación y temiendo que también terminarían huyendo. Recalde añadió que los matxines expresaron sentirse engañados "cuando les aconsejó el señor Urquijo que se retirasen a sus casas a trabajar, y que era falso lo que les habían dicho"103. Madariaga y Oleaga fueron hechos presos el día 17 de agosto en Abando, y su testimonio se limita a constatar que al día siguiente fueron libertados gracias a la persuasión de los Urquijo y Mazarredo ${ }^{104}$.

El procurador José Antonio de Ibarra recuerda cómo Urquijo dio la cara por él el día 19 de agosto, cuando se refugió en su casa huyendo de los matxines de Begoña. Urquijo no solo les reprendió en varias ocasiones para que se retirasen a sus casas, sino que cuando los alborotados insistieron en llevarse a lbarra, Urquijo mandó a Lope de Mazarredo a que fuese con ellos para que verificase que no le harían ningún daño a Ibarra y que lo dejarían libre tras entregarles un libro que pedían ${ }^{105}$.

Frente a estos testimonios, generalmente positivos a excepción del de Basaguren, Durán incluyó otros que podían incriminar a Urquijo en alguna complicidad con los matxines, aunque una lectura de los mismos desprende la poca consistencia de la acusación. El escribano Amezola formalizó por escrito las notas que había tomado Urquijo sobre las correcciones y añadidos que hicieron los vecinos de Abando del día 18. Las reivindicaciones de los abandotarras resultan de interés: pretendían que se rebajasen, o directamente se aboliesen los arbitrios que tenía que pagar el Señorío por los gastos de la Guerra de la Convención; que quedasen sin efecto los pleitos que tenía el Señorío contra la Villa y su Consulado, "de modo que las cosas quedasen en el ser y estado que tenían ahora hace 10 o 12 años"; que el plan militar se eliminase y sus ejemplares fuesen destruidos; que entendían que la última elección del nuevo gobierno del Señorío "se hizo con intención nada regular, sobornando a los vocales", se anulase y se procediera a unas nuevas elecciones, así como del consultor, figura que dejaría de ser perpetua. Además de los juicios de Amezola sobre que los vecinos de Abando "no comprendían" y que habían sido engañados por gente de Bilbao -pues querían que las cosas que-

102. AHN, Consejos, leg. 51535, pieza 12, f. 16.

103. Ibídem, ff. 17-18.

104. Ibídem, f. 18.

105. Ibídem. 
daran como estaban-, el escribano declaró que Urquijo se limitó a mirar el escrito y responder "que estaba bien"106.

Prestando testimonio contra José Nicolás de Ibargüengoitia ${ }^{107}$, el cura de Ajangiz, Eugenio López de Letona, declaró que cuando los hombres de lbargüengoitia pasaron por el pueblo dijeron que

"tenían padrinos que les protegían que les favorecían, y que uno de ellos era el Exmo. Urquijo, quien les había puesto cierta contraseña para que, cuando se leyese algún papel o capítulos dispuestos en la Junta, relativos al Servicio Militar, y ellos tuviesen que reclamar altamente, pondría con disimulo la mano en el pecho y se opusiesen a lo que él leyese, y que así lo hicieron en un día que leyó desde un balcón los tales capítulos, pues se opusieron a todos a gritos y le contestó S. E. diciendo: Bien hijos, se quitarán y borrarán"108.

Manuela de Capanaga, vecina de Gomilaz, testificó que cuando reconvino a dicha partida diciendo que iban errados, estos replicaron que "andaban segurísimos bajo la protección del Exmo. Urquijo y que S. E. les prometió que primero perdería su vida que consentir en que se les perjudicase"109. Durán anotó a continuacion de este testimonio que nada había resultado de las confesiones de los matxines y que no es cierto que se leyese ningún papel ni capítulos en la Junta de Guernica, salvo el plan de servicio militar, "que reclamaron mucho antes que fuesen Ilevados a Abando los Sres. Urquijo y Mazarredo"110.

La testificación del procurador síndico general Manuel de Oleaga, destacado miembro de la facción zamacolista que tras huir de Abando consiguió reunirse con Zamacola en Etxarri-Aranaz. Aunque ausente durante la matxinada, Oleaga fue uno de los principales colaboradores de Durán en la instrucción de la investigación de la Zamacolada"11. En su declaración contra Urquijo sacó a relucir distintos rumores que le llegaron, mezclando la amistad que le unía con algunos destacados enemigos de Zamacola con vagas insinuacions sobre complicidades con los matxines. Oleaga denunció a Durán la estrecha relación que Urquijo mantenía con José Antonio Romarate o Joaquín de Uría Nafarrondo, miembro del Consulado bilbaíno. Del primero señalaba que era el mayor confidente de Urquijo y que mientras duró la Zamacolada acudió todos los días a casa de Urquijo a

106. AHN, Consejos, leg. 51535, pieza 12, ff. 18-19.

107. El 22 de agosto Ibargüengoitia fue comisionado por una asamblea municipal de vecinos de Abando para que con una compañía de cincuenta hombres armados partiese a la búsqueda de Zamacola y Basaguren. V. GUEZALA, L.: op. cit., pp. 150-151.

108. AHN, Consejos, leg. 51535, pieza 12, f. 19.

109. Ibídem.

110. Ibídem, f. 20.

111. V. GUEZALA, L.: op. cit., p. 186. 
comer, manteniendo conversaciones muy reservadas. Con respecto a Uría, informaba de las continuas entradas en la casa de Urquijo de su mujer. Las alusiones sobre los vínculos de Urquijo con los matxines suenan aún más disparatadas. Que los matxines decían en muchas partes lo que Urquijo y Mazarredo les mandaban, que no consiguieran la libertad del consultor Aranguren, que su padre acudió la víspera del estallido de la Zamacolada al ayuntamiento de Deusto -Durán apuntó al margen que este dato era falso-, que los matxines esparcieron por toda Vizcaya la noticia de que Urquijo eran el auténtico gobernador y que tanto él como Mazarredo responderían de ellos -Durán señaló también al margen que de esta información solo ha sido confirmada por las declaraciones de López de Letona y Capanaga-, que Urquijo escribió un decreto para la apertura de los papeles -que según Durán queda copiado-, que se había vendido al rey el Señorío en quince millones de reales, etc. ${ }^{112}$

Nada de incriminatorio había en aquellas declaraciones, teniendo en cuenta el escaso fundamento de las acusaciones. Era evidente además la hostilidad de Oleaga y Basaguren, quienes habían tratado con Zamacola antes de ser interrogados por Durán. El proceso, sin embargo, iba a seguir y Godoy exigió a Durán que le remitiera el interrogatorio que realizó a Urquijo ${ }^{113}$. Éste, cuyo contenido hemos comentado en el apartado anterior, estaba constituido por once preguntas a las que Urquijo tuvo que responder detalladamente por escrito. Éstas, que contenían diversas sospechas sobre su conducta durante la Zamacolada, fueron:

$1^{\text {a })}$ Si ordenó a Basaguren que pasara a Dima con gente armada para publicar el bando, que establecía que nadie tomara armas bajo pena de muerte, sabiendo que tenían el encargo de arrestar a Zamacola.

$2^{a}$ ) Si anteriormente habló con Basaguren en su gabinete sobre dicha prisión, diciéndole que Zamacola "no podía atreverse a resistr el país porque había caído en desgracia", y que aunque Basaguren quería ser exonerado de la comisión, Urquijo le espetó que no tenía otro remedio, y que si se negaba los matxines que había en la casa pedirían que fuese entregado, y sería preciso entregarlo, para matarlo.

$3^{\text {a }) ~ S i ~ n o ~ h a b i e n d o ~ b a s t a d o ~ l a s ~ e x c u s a s ~ d e ~ B a s a g u r e n ~ n i ~ s u ~ p r e t e x t o ~ d e ~ s e r ~}$ amigo de Zamacola, que le eximía de cometer contra él una traición, Urquijo ordenó a veintidós hombres que había en la casa para que acompañaran a Basaguren, previniendo que le tratasen bien, porque de lo contrario Basaguren les abandonaría y marcharía del país. Que no le dejasen hablar con nadie, que no disparasen fusiles y que en Dima

112. AHN, Consejos, leg. 51535, pieza 12, f. 20.

113. El príncipe de la Paz a Durán. Aranjuez, 29-I-1805. Ibídem, f. 21. 
Basaguren solo pudiese decir lo que ponía el bando acompañado de seis hombres desarmados.

4a) Si en el ayuntamiento de Abando, donde el día 18 de agosto, donde estaban presos el corregidor y los diputados generales, intervino en la formación o modificación de cuatro decretos.

$5^{\text {a) }}$ Si de resultas de haberse ordenado en uno de tales decretos la celebración de Juntas Generales en Gernika el 22 de agosto, pasó un papel al fiel de Abando para que se nombrasen apoderados de toda satisfacción, dando además instrucciones para la extensión del poder que iban a llevar los representantes; si después de ver el documento manifestó que estaba bien.

$\left.6^{\underline{a}}\right)$ Si también dio las instrucciones anteriores a la anteiglesia de Begoña.

$7^{a}$ ) Si durante las Juntas Generales del 26 de agosto dio un recado para que bajasen a su casa los fieles de Begoña, comunicando que había recibido una carta del corregidor donde advertía que los begoñeses insistían en la apertura de los baúles, y que si esto se hacía no salía responsable de sus resultas. Si los de Begoña respondieron que los vecinos no dejarían de estar alborotados no abriéndose los baules. Tras oír eso Urquijo se dispuso a dictarles un acuerdo para los apoderados de Begoña en las Juntas, adoptándolo la anteiglesia "con algazara, vivas y gritería".

$8^{\text {a) }}$ Si el acuerdo decía textualmente "que la anteiglesia quería y pedía que los cofres se abriesen en presencia de la Junta general".

9a) Si tratándose sobre ese punto de apertura, cierta persona, que portaba un papel sobre el mismo, estuvo a punto de quedar preso en Abando, y temiendo este destino se lo comunicó a Urquijo, quien contestó que no le podían hacer nada. Como a pesar de todo lo apresaron, esta persona se disculpó diciendo que lo había hablado con Urquijo; que los de Abando inquirieron sobre ello a Urquijo y les contestó que le dejasen, logrando así la libertad.

$\left.10^{\mathrm{a}}\right) \mathrm{Si}$ al retirarse Urquijo de Abando el 18 de agosto acompañado del corregidor se hizo encargo a uno de los regidores de Bilbao para que entregase pólvora a los matxines de Abando.

$\left.11^{a}\right)$ Qué sentido tuvo la pregunta de si los de Otxandio se alistaron para el servicio militar, si les hizo presente el plan y qué respondieron ${ }^{114}$.

El 23 de mayo de 1805, una vez estudiadas todas las declaraciones, interrogatorios y pruebas, se dictó real sentencia sobre los sucesos de la Zamacolada, con penas individuales y colectivas. Textualmente declaraba:

114. AHN, Consejos, leg. 51535, pieza 12, ff. 22-23. 
"aunque la conducta observada por el Sr. D. Mariano Lis de Urquijo, D. José de Mazarredo y D. Francisco Policarpo de Urquijo no se ha descubierto ser criminosa, de lo que S. M. se da por servido, es su Soberana voluntad, que tanto estos como D. José de Colón, fijen su residencia fuera del Señorío a distancia de veinte leguas y también lo verificarán de Madrid y Sitios Reales"115.

Nada había sido probado en contra de los Urquijo ni Mazarredo. No solo eso: quedaba demostrado que habían evitado el estallido de un enfrentamiento en el Señorío de Vizcaya mediando entre los matxines con prudencia y talento. Frente a las artimañas de los zamacolistas o los recelos de Murga, los Urquijo y Mazarredo revirtieron la situación ateniéndose al marco foral ${ }^{116}$. Esta fue la causa de su ruina. Aunque solo ejercieron de apagafuegos, con su comportamiento impidieron que los confluentes planes de la Corte y los zamacolistas pudieran Ilevarse a cabo. No podían ser acusados de haber atentado contra la monarquía o los fueros, pero sí contra unos intereses particulares, buscando el bien común. Cabe alegar que lo hicieron forzados, pero a continuación debiera señalarse que cumplieron fielmente los compromisos contraídos con los matxines. No pueden tributarse los mismos elogios a otros personajes que tan solo se preocuparon por su propia seguridad, desatendiendo sus obligaciones y poniendo en peligro al resto.

Pensando ser premiados, los Urquijo y Mazarredo recibieron un duro correctivo. Lo contrario hubiera supuesto condenar la actuación de los zamacolistas, que, en definitiva, habían defendido los intereses particulares de la monarquía.

\section{A modo de conclusión}

La ocupación militar del Señorío, que se prolongó hasta marzo de 1807, y las condenas a casi cuatrocientas personas, muchas de ellas arbitrarias, no fueron las únicas respuestas de la monarquía a la revuelta de la Zamacolada. Las autoridades designadas en las Juntas Generales de agosto fueron depuestas, los polémicos decretos aprobados por las Juntas de julio continuaron adelante y una multa de más de doce millones de reales. El impacto en el pueblo vizcaíno fue enorme, sin que consiguiera disiparlo el indulto general que concedió Godoy cuando fue nombrado almirante general en $1807^{117}$. Significó además una brecha importante en la tensión entre foralismo y centralismo. Juan Anto-

115. AHN, Consejos, leg, 2870/3, reproducido en VILLABASO, C.: op. cit., Apéndice VII, pp. 221-222.

116. Luis de Guezala matiza el carácter revolucionario de la Zamacolada, pues la actuación de los matxines siempre estuvo encaminada "a impedir una modificación del ordenamiento foral en lo relativo al servicio militar". Cfr. GUEZALA, L.: op. cit., p. 197.

117. V. GUEZALA, L.: op. cit. pp. 188 y 198-199; RIBECHINI, C.: op. cit., pp. 133-138. 
nio Llorente fue autorizado en 1805 para que registrase el archivo del Señorío en busca de documentos que sustentasen la tesis de que los fueros eran una concesión de los monarcas ${ }^{118}$.

En sus Memorias el príncipe de la Paz consignó su visión personal sobre los hechos. Lo que en realidad pretendieron los matxines era derribarle -"el tiro era directo en contra mía"-, sirviéndose como pretexto de los prejuicios que sufriría la villa de Bilbao con la construcción del nuevo Puerto de la Paz. Recuerda a renglón seguido que precisamente fue la Junta General quien solicitó la construcción del puerto. "¿Quién cambió las ideas? ¿Quién alteró los ánimos?”, se pregunta Godoy, respondiendo:

"No fue dado saberlo en aquel tiempo, ninguno dio la cara [...]; un gran número de reos y testigos preguntados, ni aun sabían dar razón de los motivos que causaron aquel alarde sedicioso, en que los más entraron como máquinas, creyendo vagamente algunos que se trataba de sus fueros ${ }^{\prime \prime 119}$.

Precisamente es en 1804 cuando se observa una generalización en diversos territorios de la monarquía de la crítica hacia el príncipe de la Paz ${ }^{120}$, dando cauce a una crisis política que primero desembocaría en la conjura de El Escorial y finalmente en el motín de Aranjuez, que terminaría con el reinado de la "Santísima Trinidad": Carlos IV, María Luisa y Godoy. Preocupado tan solo del recuerdo para la posteridad, el anciano Godoy de las Memorias atribuye el malestar popular existente a extrañas conspiraciones lanzadas en contra de su persona.

La apología fue también un recurso utilizado por Urquijo y Mazarredo para lavar su nombre. La representación que Mazarredo elevó al príncipe de la Paz a finales de 1804, escrita desde Santoña -a donde llegó tras pasar por la localidad riojana de Casalarreina-, fue finalmente impresa en 1810 en el Madrid josefino $^{121}$. Urquijo dejó manuscritos unos Apuntes para la memoria sobre mi vida política, persecuciones y trabajos padecidos en ella, fechados en Bilbao el 20 de diciembre de 1806, donde da rienda suelta a la frustración experimentada durante todos los años pasados desde su desgracia en la Corte. Del proceso

118. Su resultado fue la obra Noticias históricas de las tres provincias vascongadas, Madrid, Imprenta Real, 1806.

119. Al final habría de recordar, valiéndose de uno de sus grandes recursos exculpatorios, que a pesar de sus oficios a favor de Bilbao prevaleció José Antonio Caballero, ministro de Justicia, "iy era yo generalísimo!". V. GODOY, Manuel: Memorias, edición de Emilio La Parra y Elisabel Larriba (eds.), Alicante, Publicaciones de la Universidad de Alicante, 2008, pp. 988-989.

120. V. LA PARRA, Emilio: Manuel Godoy. La aventura del poder, Barcelona, Tusquets, 2002, p. 335.

121. Representación de Don Joseph de Mazarredo al señor rey D. Carlos Quarto sobre su ostracismo en Bilbao, Madrid, Imprenta de Ibarra, 1810. 
originado por la Zamacola apunta que existían dudas sobre su conducta y que sobre la sentencia, "la contradicción [...] se deja ver por sí sola"122.

Desde Santoña Mazarredo fue conducido a Pamplona, donde permaneció hasta que en 1807 se le permitió regresar a Bilbao ${ }^{123}$. Las peripecias de Urquijo son mejor conocidas. Al ser transferido su padre Francisco Policarpo a Logroño, Mariano Luis debió de solicitar el traslado a la ciudad del Ebro. En el acta de sesiones del ayuntamiento logroñés del 7 de noviembre de 1805 se comisiona al procurador mayor del mismo para que vaya a darle la bienvenida ${ }^{124}$. Durante su estancia en el pequeño municipio de Urquijo la principal actividad pública fue asistir al teatro, una de sus viejas pasiones. Tendría también ocasión de charlar con su vieja amiga María Francisca de Sales Portocarrero, que se hallaba desterrada en Logroño desde 1805 acusada de jansenista ${ }^{125}$. El 13 de septiembre de 1806 las actas del ayuntamiento recogían que Mariano Luis de Urquijo había notificado su regreso a Bilbao, "expresando los vivos deseos que tenía de servir a la Ciudad por lo agradecido que estaba de los favores que se le han franqueado por este llustre Ayuntamiento, y que así lo indicase, como también que donde quiera que se halle se sacrificará en obsequio de esta Ciudad"126. Posteriormente, Urquijo y Mazarredo fueron rehabilitados y ocuparon destacados puestos de responsabilidad en el gobierno con la monarquía josefina, pero eso ya es otra historia.

Otro de los implicados, el intrigante Simón Bernardo de Zamacola, tuvo un destino más aciago. En 1805, después de que la represión ajustara las cuentas con matxines y personajes opuestos a su facción, Zamacola regresó a su envidiado puesto como representante del Señorío en la Corte. Ójala no lo hubiera hecho, pues los sinsabores que sufrió en Madrid terminaron con él. Pese a sus designios contra la villa de Bilbao, Zamacola era en el fondo foralista y no supo calibrar la decidida voluntad centralista de la Corte. Durante esta etapa se vio obligado a sufrir disgustos humillaciones y desaires hasta que el 16 de enero de 1806, tras una tormentosa audiencia con Godoy, sufrió un ataque que le privó de la cordura. Tuvo que ser llevado a Vizcaya donde murió tres años más tarde ${ }^{127}$.

Las voluntades humanas se ven superadas por los acontecimientos, y este caso no fue una excepción. El motín de Aranjuez, la Guerra de la Independencia y la restauración del absolutismo restauraron el ordenamiento foral anterior a los sucesos de la Zamacolada.

122. V. URQUIJO, M. L.: op. cit., p. 107.

123. V. BARBUDO DUARTE, E.: op. cit., p. 126.

124. A. M. Lo., Actas del ayuntamiento, sesión extraordinaria 7-XI-1805.

125. V. DEMERSON, Paula de: María Francisca de Sales Portocarrero, condesa de Montijo: una figura de la llustración, Madrid, Editora Nacional, 1975, p. 335.

126. A. M. Lo., Actas del ayuntamiento, sesión ordinaria, 13-IX-1806.

127. V. RODRíGUEZ GARCíA, Francisco: Crónica General del Señorío de Vizcaya, Madrid, Aquiles Ronchi, 1865 (reimp. 2002), pp. 88-89. 